\title{
STRATEGI PHYSICAL SELF ASSESMENT UNTUK PENINGKATAN PEMAHAMAN DALAM PEMBELAJARAN PKn SISWA SMP
}

\author{
Oleh: \\ Novina Andriyanti \\ Universitas Muhammadiyah Surakarta
}

\begin{abstract}
Abstrak
Pendidikan bersifat normatif yaitu bersumber pada tugas-tugas perkembangan dan kriteria kedewasaan. Pendidikan sebagai suatu kegiatan yang di dalamnya melibatkan banyak orang, diantaranya peserta didik, pendidik, administrator, masyarakat, dan orang tua peserta didik. Oleh karena itu, agar tujuan pendidikan dapat tercapai secara efektif dan efisien, maka setiap orang yang terlibat dalam pendidikan dapat memahami tentang perilaku individu dan dapat menunjukkan perilakunya secara efektif. Penerapan strategi Physical Self Assesment telah mampu meningkatkan pemahaman siswa materi demokrasi hingga sebanyak 21 siswa atau $79 \%$ dari 27 siswa memenuhi Kriteria Ketuntasan Minimal (KKM). Pemahaman siswa meningkat yaitu sebelum diadakannya tindakan dengan menggunakan strategi Physical Self Assesment siswa yang memahami materi demokrasi sebanyak 9 siswa atau 45\% dari 27 siswa memenuhi Kriteria Ketuntasan Minimal (KKM). Kemudian setelah diberi tindakan dengan strategi Physical Self Assesment pada siklus I sebanyak 15 siswa atau 52\% dari 27 siswa memenuhi Kriteria Ketuntasan Minimal (KKM), dan pada siklus II sebanyak 21 siswa atau 79\% dari 27 siswa memenuhi Kriteria Ketuntasan Minimal (KKM).
\end{abstract}

Kata Kunci: Strategi, Phsical Self Assesment, Pemahaman, PKn, Siswa 


\section{Pendahuluan}

Masalah yang dihadapi oleh siswa di kelas dalam mengikuti proses pembelajaran sangat beragam sekali, misalnya tentang sulitnya memahami materi, keaktifan siswa yang sangat kurang, dan partisipasi siswa yang masih rendah dalam pembelajaran. Hal ini mendorong tenaga pendidik untuk menciptakan kreasi yang baru dalam proses belajar mengajar, agar siswa tidak merasa bosan dalam mengikuti pembelajaran di kelas. Perbaikan kualitas pendidikan tersebut, sampai saat ini tidak pernah berhenti, usaha tersebut dilakukan untuk penyesuaian dan mengimbangi perkembangan pendidikan.

Strategi yang digunakan dalam proses pembelajaran sangat beragam, hal itu diterapkan sesuai dengan kemampuan guru dalam mengelola kelas. Pembelajaran konvensional yang sebagian besar hanya mengandalkan ceramah saja tentu tidak akan mendukung tujuan pembelajaran secara ideal. Ceramah tidak harus dihindari sama sekali, tetapi penggunaannya harus tepat sesuai dengan kebutuhan. Ceramah saja dapat dikatakan belum sepenuhnya sesuai dengan kebutuhan siswa dalam mendapatkan materi, sehingga siswa yang dituntut harus aktif dan selalu tanggap dalam proses pembelajaran di kelas.

Mata Pelajaran Pendidikan Kewarganegaraan mengandung banyak materi yang harus dipahami oleh siswa, dalam hal ini guru dituntut untuk menciptakan sebuah strategi pembelajaran yang harus diterapkan pada siswa. Strategi yang akan diterapkan tersebut, tidak hanya siswa saja yang benar-benar melaksanakan dengan baik, tetapi sebelum strategi tersebut benar-benar diterapkan, guru pada awalnya harus menyiapkannya dengan matang dan harus disesuaikan dengan kebutuhan materinya. Seorang guru harus mampu memilih dan mempertimbangkan implementasi strategi pembelajaran yang benar-benar dapat mengaktifkan peserta didik. Seorang guru yang profesional perlu memahami dan melaksanakan tuntutan profesionalitas, baik secara administratif, akademis, maupun praktis serta mendesain sebuah pembelajaran yang harmonis.

Penelitian Tindakan Kelas (PTK) merupakan suatu penelitian yang akar permasalahannya muncul di kelas dan dirasakan langsung oleh guru yang bersangkutan, sehingga sulit dibenarkan jika ada anggapan bahwa permasalahan dalam PTK muncul dari rekayasa peneliti. Oleh karena itu, perlu adanya bukti dari sekolah sehingga hasil PTK yang telah dilakukan bukan merupakan rekayasa peneliti. Pada intinya PTK bertujuan untuk memperbaiki berbagai persoalan nyata 
dalam peningkatan mutu pembelajaran di kelas yang dialami langsung dalam interaksi antara guru dengan siswa yang sedang belajar. PTK yang dikaitkan dengan pengelolaan kelas dapat dilakukan dalam rangka meningkatkan kegiatan belajar-mengajar, meningkatkan partisipasi siswa dalam belajar, menerapkan pendekatan belajar-mengajar inovatif, dan mengikutsertakan pihak ketiga dalam proses belajar-mengajar.

Pokok bahasan mengenai demokrasi merupakan pokok bahasan kelas VIII B SMP. Materi demokrasi tersebut yaitu meliputi pengertian dan sejarah perkembangan demokrasi, macammacam demokrasi, nilai-nilai demokrasi, pentingnya kehidupan demokrasi, pengertian demokratisasi, prinsip-prinsip demokrasi, demokrasi di Indonesia, perbandingan pelaksanaan demokrasi di Indonesia, dan sikap positif terhadap pelaksanaan demokrasi dalam berbagai kehidupan. Penerapan strategi Physical Self Assesment dalam penelitian ini, diharapkan dapat meningkatkan pemahaman siswa mengenai materi demokrasi dalam pembelajaran Pendidikan Kewarganegaraan dan menjadikan siswa lebih aktif dan kreatif dalam mengembangkan daya pikirnya.

Kondisi awal siswa kelas VIII B di SMP N 3 Tawangsari sebelum diterapkannya strategi Physical Self Assesment, yaitu tingkat pemahaman dan keberanian berpendapatnya masih rendah. Kurangnya percaya diri siswa mengakibatkan lemahnya keberanian untuk bertanya sehingga mereka membiarkan dirinya untuk tidak tahu dan tidak paham terhadap materi yang telah diajarkan. Guru hanya dibiarkan aktif berceramah sedangkan siswa hanya mendengarkan penjelasan dari guru, padahal dalam pengembangan Kurikulum Tingkat Satuan Pendidikan (KTSP) tidak dibenarkan seperti itu. Kondisi awal sebelum diterapkannya strategi Physical Self Assesment, mengenai tingkat pemahamannya bisa dikatakan cukup rendah yaitu hanya sembilan (9) siswa yang memenuhi Kriteria Ketuntasan Minimal (KKM) dari 27 siswa dan yang tidak memenuhi KKM sebanyak delapan belas (18) siswa, itu berarti siswa belum benar-benar memahami materi demokrasi secara keseluruhan. Diharapkan setelah strategi Physical Self Assesment ini diterapkan pada siswa kelas VIII B, pemahaman siswa menjadi bertambah $75 \%$ dari 27 siswa, yaitu minimal dua puluh satu (21) siswa yang harus memenuhi KKM.

Berdasarkan latar belakang masalah yang telah diuraikan, akan dilakukan penelitian dengan judul "Upaya Meningkatkan Pemahaman Materi Demokrasi Melalui Penggunaan 
Strategi Physical Self Assesment dalam Pembelajaran Pendidikan Kewarganegaraan pada Siswa Kelas VIII B SMP Negeri 3 Tawangsari Sukoharjo Tahun Pelajaran 2010-2011”.

\section{Kajian Teori}

Pengertian Strategi Physical Self Assesment. Menurut Zaini (2007:74-75), yang dikutip oleh Wiselmi bahwa "strategi ini merupakan suatu strategi pembelajaran yang menuntut guru untuk mengetahui sejauh mana pemahaman siswa atas materi dan sejauh mana hasil belajar yang dicapai oleh siswa". Strategi Physical Self Assesment ini memang relatif sederhana tetapi mempunyai pengaruh yang kuat karena dapat membuat siswa tertarik dan menyenangkan, serta dapat mengubah aktivitas kelas menjadi lebih dinamis. Disamping itu strategi Physical Self Assesment ini, dapat membuat siswa tertantang, berusaha untuk betul-betul mamahami materi pelajaran, mendorong keranian untuk bertanggung jawab dan mengambil resiko.

Prosedur atau Langkah-langkah Pelaksanaan Strategi Physical Self Assesment. Menurut Siberman (2009:266-267) langkah-langkah pelaksanaan strategi ini yaitu:

1. Buatlah satu pertanyaan atau lebih yang menilai peserta didik berubah. Contoh-contohnya bisa mencakup:

- Saya telah mengubah pendapat saya tentang__ karena pelajaran ini.

- Saya telah mengembangkan kecakapan saya dalam

- Saya telah belajar informasi dan konsep baru

2. Singkirkan kursi-kursi atau bangku-=bamgku ke satu sisi dan perintahkan peserta didik dududk di belakang ruangan.

3. Buatlah skala rating angka dari 1-5 di depan ruangan dengan menggunakan papan tulis atau menempatkan angka di dinding.

4. Jelaskan bahwa pernyataan akan dibaca di hadapan kelas. Setelah mendengar masingmasing, peserta didik harus berdiri di depan rating angka yang paling cocok dengan penilaian dirinya.

Gunakan skala berikut ini:

$1=$ sangat tidak setuju

$2=$ tidak setuju

$3=$ tidak yakin

$4=$ setuju

5 = sangat setuju

5. Ketika setiap pertanyaan dibaca, peserta didik harus pindah tempat di ruang yang paling cocok dengan penilaian dirinya. Doronglah peserta didik untuk menilai dirinya secara realistis. Tunjukkan beberapa faktor yang mungkin membuat sedikit perubahan atau tidak berubah, faktor-faktor itu termasuk tingkat pengetahuan atau tidak berubah, faktor-faktor itu termasuk tingkat pengertahuan dan keterampilan sebelumnya, perlunya latihan dan waktu yang lebih, dan seterusnya. 
6. Setelah bentuk garis di depan beragam posisi, ajaklah beberapa peserta didik untuk berbagi mengapa memilih rating tersebut. Garis bawahi kejujurannya.

7. Setelah mendengar opini yang lain, ajaklah siapa saja yang ingin mengubah posisisnya pada skala untuk melakukannya juga.

Melalui strategi ini diharapkan sekali pemahaman siswa menjadi meningkat, mengingat permasalahan yang telah disebutkan di atas, peneliti merasa tertantang untuk menerapkan strategi dan melakukan Penelitian Tindakan Kelas (PTK) di sekolah tersebut. Mengetahui sejauh mana pemahaman siswa, keaktifannya, dan juga keberaniannya dalam mengemukakan pendapatnya di depan kelas melalui materi demokrasi ini. Berdasarkan kajian teoritis sebagaimana telah dipaparkan di atas, maka dalam penelitian ini perlu mangajukan anggapan dasar atau kerangka pemikiran sebagai berikut:

1. Penerapan strategi Physical Self Assesment ini akan meningkatkan pemahaman materi demokrasi.

2. Penggunaan strategi Physical Self Assesment akan melibatkan siswa dalam proses pembelajaran Pendidikan Kewarganegaraan.

3. Penerapan strategi Physical Self Assesment akan meningkatkan prestasi belajar siswa pada mata pelajaran Pendidikan Kewarganegaraan.

Bila digambarkan maka akan tampak sebagaimana gambar siklus berikut ini.

\begin{tabular}{|c|c|c|}
\hline Kondisi Awal & Tindakan & Kondisi Akhir \\
\hline$\downarrow$ & $\downarrow$ & $\downarrow$ \\
\hline $\begin{array}{l}\text { 1) Guru sebelum } \\
\text { menggunakan Strategi } \\
\text { Physical Self Assesment. } \\
\text { 2) Pemahaman siswa } \\
\text { kurang. }\end{array}$ & $\begin{array}{l}\text { Penggunaan Strategi } \\
\text { Physical Self } \\
\text { Assesment melalui } \\
\text { materi demokrasi. }\end{array}$ & $\begin{array}{l}\text { Diduga penggunaan Strategi } \\
\text { Physical Self Assesment } \\
\text { meningkatkan pemahaman } \\
\text { materi demokrasi. }\end{array}$ \\
\hline
\end{tabular}

Hipotesis yang akan diajukan oleh peneliti adalah "Diduga melalui penerapan Strategi Physical Self Assesment dapat meningkatkan pemahaman materi demokrasi dalam proses pembelajaran Pendidikan Kewarganegaraan pada siswa kelas VIII B SMP Negeri 3 Tawangsari Kabupaten Sukoharjo Tahun Pelajaran 2010-2011”. 


\section{Metode Penelitian}

Tempat penelitian adalah di SMP Negeri 3 Tawangsari Tahun Pelajaran 2010-2011. Tahaptahap pelaksanaan kegiatan, sejak persiapan sampai dengan penulisan laporan penelitian, secara keseluruhan dilakukan selama kurang lebih empat bulan, yaitu sejak bulan Maret sampai dengan bulan Juni 2011. Subyek penelitian tindakan ini adalah siswa dan guru mata pelajaran Pendidikan Kewarganegaraan SMP Negeri 3 Tawangsari. Siswa yang dijadikan subyek penelitian ini adalah siswa kelas VIII B SMP Negeri 3 Tawangsari. Siswa kelas VIII B berjumlah 27 orang dan guru yang dijadikan subjek penelitian ini adalah guru mata pelajaran PKn kelas VIII B SMP Negeri 3 Tawangsari.

Model penelitian tindakan kelas adalah "secara garis besar terdapat empat tahapan yang lazim dilalui, yaitu (1) perencanaan (2) tindakan, (3) observasi, (4) refleksi. Jenis Penelitian Tindakan Kelas ini menggunakan jenis penelitian kualitatif, karena penelitian kualitatif tidak menggunakan pendekatan populasi dan sampel, tetapi istilah yang digunakan adalah setting penelitian (tempat penelitian). Untuk mengumpulkan data dalam kegiatan penelitian diperlukan cara atau teknik pengumpulan data tertentu, sehingga proses penelitian dapat berjalan dengan lancar. Metode pengumpulan data yang digunakan dalam Penelitian Tindakan Kelas ini yaitu metode observasi, metode tes, dan metode angket (kuesioner).

Penelitian ini menggunakan dua macam triangulasi, yang pertama triangulasi sumber data yang berupa informasi dari guru mata pelajaran PKn dan siswa kelas VIII B SMP Negeri 3 Tawangsari. Kedua triangulasi teknik atau metode pengumpulan data yang berasal dari hasil observasi dan tes tertulis. Analisis data dalam Penelitian Tindakan Kelas (PTK) ini menggunakan analisis data model alir. Dalam penelitian ini instrumen yang telah ditetapkan yaitu:

1. Instrumen untuk metode observasi adalah check list. Dalam penelitian ini peneliti akan memberikan tanda check list pada setiap aktivitas yang dimaksud.

2. Instrumen untuk metode tes adalah tes atau soal tes. Pada Penelitian Tindakan Kelas ini, peneliti akan memberikan soal tes yang menyangkut tentang materi demokrasi.

3. Instrumen untuk metode angket atau kuesioner adalah angket atau kuesioner mengenai materi demokrasi pada pembelajaran Pendidikan Kewarganegaraan. 


\section{Hasil Penelitian dan Pembahasan}

Diterapkannya strategi Physical Self Assesment ini telah meningkatkan pemahaman siswa pada materi lembaga peradilan, terbukti pada hasil tes siswa pada tindakan siklus II. Strategi ini disambut baik oleh siswa itu sendiri, karena strategi pembelajaran yang diterapkan ini dianggap baru sehingga memberikan inovasi pada pembelajaran Pendidikan Kewarganegaraan. Tindakan siklus I belum menunjukkan bahwa pemahaman siswa mengalami peningkatan, dikarenakan siswa baru tahap pengenalan terhadap strategi dan cara mengajar dari peneliti itu sendiri yang belum dipahami oleh siswa.

Tindakan siklus II telah memberikan warna yang berbeda pada siswa kelas X 5, siswa yang semula kurang aktif dalam bertanya, dia memberanikan diri untuk bertanya, sehingga membuat proses pembelajaran semakin hidup. Pada tindakan siklus I dapat diketahui bahwa siswa yang memenuhi Kriteria Ketuntasan Minimal (KKM) hanya 15 siswa yaitu 52\% dari 27 siswa sedangkan pada tindakan siklus II sudah mengalami peningkatan yaitu siswa yang memenuhi Kriteria Ketuntasan Minimal (KKM) mencapai 21 siswa yaitu 79\% dari 27 siswa. Hal ini menandakan bahwa dengan penerapan strategi Physical Self Assesment dapat meningkatkan pemahaman materi lembaga peradilan pada siswa kelas X 5 di SMA N 3 Tawangsari.

\section{Simpulan}

Dari rangkaian putaran penelitian tindakan kelas yang telah dilakukan terlihat adanya perubahan yang merupakan hasil penelitian dalam rangka usaha meningkatkan pemahaman siswa pada materi demokrasi. Bertitik tolak dari tindakan yang telah dilaksanakan pada penelitian ini, maka dapat memberikan beberapa kesimpulan sebagai berikut:

1. Penerapan strategi Physical Self Assesment telah mampu meningkatkan pemahaman siswa materi demokrasi hingga sebanyak 21 siswa atau 79\% dari 27 siswa memenuhi Kriteria Ketuntasan Minimal (KKM).

2. Pemahaman siswa meningkat yaitu sebelum diadakannya tindakan dengan menggunakan strategi Physical Self Assesment siswa yang memahami materi demokrasi sebanyak 9 siswa atau 45\% dari 27 siswa memenuhi Kriteria Ketuntasan Minimal (KKM). Kemudian setelah diberi tindakan dengan strategi Physical Self Assesment pada siklus I sebanyak 15 siswa atau 52\% dari 27 siswa memenuhi Kriteria Ketuntasan Minimal (KKM), dan pada siklus II sebanyak 21 siswa atau 79\% dari 27 siswa memenuhi Kriteria Ketuntasan Minimal (KKM). 